\title{
ヘレニズム時代までのギリシアの劇場の舞台と客席との位置関係について ON RELATIONSHIP BETWEEN THE POSITIONS OF STAGE BUILDING AND CAVEA OF GREEK AND HELLENISTIC THEATERS IN ANCIENT GREECE
}

\author{
渡邊道治* \\ Michiharu WATANABE
}

\begin{abstract}
This paper discusses about some features in the positions of stage building and cavea of twenty-three Greek and Hellenistic theaters constructed in Greece through a geometrical analysis. As a result, the following four points are drawn out; (1) the positions of stage building and cavea are related each other by a circle or a regular polygon inscribed in an another circle, (2) of the circle described above are there two patterns, one equals to a orchestra and the other corresponds to a circle of which diameter is taken between the lowest steps of cavea, (3) after an introduction of a permanent proscenium, it happened in most theaters that one side of a regular polygon coincides with a position of front of the proscenium, (4) around Athens there are a few theaters with particularities, in which a position of front of a proscenium coincides with one side of a regular polygon inscribed in a circle while keeping a circular orchestra space.
\end{abstract}

Keywords : theater, greek, hellenistic, geometrical analysis, cavea, proscenium 劇場、ギリシア時代、ヘレニズム時代、幾何学分析、客席、プロスケニオン

\section{1. 研究の目的と方法}

劇場建築はギリシア・ローマ時代に数多く建設され、この時代に ひとつの建築タイプとして確立された。ギリシアのアルカイック時 代から西ローマ帝国滅亡までの期間に地中海世界に確認できる劇場 （オデイオンも含む）は 900 例ほどにおよぶ(1)。劇場が観劇を主目 的とすることから、その平面計画において客席と舞台建築（本稿で は舞台を演者が演じるための部分のみ、つまり一段高くなった部分 のみに限定して用い、舞台を含む演劇を演じるための建物全体を舞 台建筑と称する）の位置関係がきわめて重要なことは当然のことで ある。そこで本稿の目的は、現存する遺構をもとに、ギリシア時代 からへレニズム時代にかけてのギリシアに残る劇昜において、客席 と舞台建築との配置に関して円と正方形以外の正多角形を介しても 位置関係が存在したことを明らかにすることである。ギリシア演劇 がギリシアの地に生まれ発展した中で、それを上演した劇場もギリ シアの地で生み出され、その後のギリシア、ヘレニズム、ローマ世 界で建設されてきたのであるから、本稿ではまずギリシアに地域を、 そしてギリシアとへレニズム時代に時期を、限定して分析を行った。

分析にあたって遺構の保存状態が良く、精緻な発掘報告がなされ ている 14 例と、実測寸法は欠けているものの分析可能な平面図が
報告されている9 例、合計 23 例を対象とした。その際に客席や舞台 が改修や改筑、あるいは再建されてその平面が大きく変化した場合 には異なる劇場として取り上げることとした。これまでの研究によ ってギリシアにはへレニズム時代までに 95 の劇場が建設されてい たことが確認できている。その中で客席と舞台建築の両者の位置を

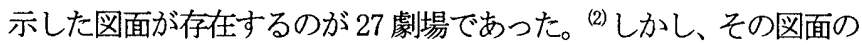
精度およひ発掘報告書の内容椂々であり、本稿の分析に使用でき る図面精度と発掘調查内容を備えているものは 23 劇場であった。

分析に際して、現存遺構に最も適合する円と正多角形を想定し、 遺構の実測值との相違が最も小さい図形を求めた。なぜなら、ウィ トルウィウスはオルケストラの円（あるいは「底の円」）とそれに内 接する正方形の一辺がスカエナとプロスケニオンの位置に一致する と記述しているからである。本稿では正多角形に関しては、ウィト ルウィウスの記述から、最大で正十二角形までとした。(3)

\section{2. 研究の背景}

ギリシアの劇場の平面の割り付けについて記述した唯一の古代の文 献史料である建築十書において、ウィトルウィウスはギリシア劇場 では基準となる円がスカエナに接し、その円に内接する正方形の一 辺がロゲイオンの前面に一致しており、ローマ劇場では基準となる

\footnotetext{
* 九州東海大学工学部建築学科 教授・博士 (工学)
}

Prof., Dept. of Architecture, Faculty of Engineering, Kyushu Tokai University, Dr. Eng. 
円に内接する正三角形の一辺がスカエナの前面に一致し、その一辺 に平行に円の中心を通る直線の位置にプロスケニオン（=プロスカ エニウム、ロゲイオン) が置かれると述べている。すなわち、基準 となる円とそれに内接する正二角形もしくは正方形を用いてギリシ アとローマの劇場の客席と舞台との平面上の位置関係が定められる と指摘している。(図 1) (4)

このウィトルウィウスの記述の手がかりとし、現存するギリシア 型劇場（客席平面が半円を超えた扇形をなし、かつ舞台建築と客席 が個別に立つタイプの劇場）の平面おける客席と舞台建築との平面 上の位置関係に関する研究が行われてきた。まずドウルプフェルド が、ギリシアの劇場ではオルケストラの円がスカエナに接する、あ るいはプロスケニオンに接することを基本に計画されていると指摘 した。(5)次いでプフシュタインがウィトルウィウスのギリシア劇場 に関する記述はヘレニズム時代の劇場の舞台に一致すると主張した。 その後フィーヒターによってより多くの事例を対象とした包括的な 研究がなされ、オルケストラの円がスカエナに接する場合と、その 円に内接する正方形の一辺がプロスケニオンの位置に一致する場合

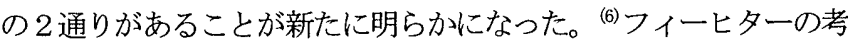
えは、ビーバーやシアなどのその後の研究者に継承されてきた。(7)

こうした研究を包括するような形でディンズモアは劇場建築の 建築的な発展と関連づけて以下の諸点を指摘している。 ${ }^{(8)}$ (a) プロ スケニオン出現以前ではオルケストラは円形平面をなし、その円に 接する位置にスカエナが置かれるか、あるいはその円よりも外側に 置かれた。(b)石造の恒久的なプロスケニオンが建設されるようにな るとプロスケニオンはオルケストラの円を横断する位置に置かれる ようになった。またプロスケニオンが当初から建設された劇場のな かにはオルケストラの円がスカエナに接する例が若干見られる。(c) モニュメンタルな劇場では基準となる円の中心にスカエナがより近 付き、そのオルケストラの円がスカエナに接する例が見られる。(d) アテネのように古典演劇の伝統が根強い地域ではプロスケニオンが 建設されても、それがオルケストラの円の内側に位置するようなこ とはない。(e)プリエネの劇場のみで基準となる円がスカエナに接し、 その円に内接する正方形の一辺がプロスケニオンの位置に一致する、 つまりウィトルウィウスの述べるギリシア型劇場の配置の方法に完 全に一致する。

これらの既往研究はウィトルウィウスのギリシア型劇場平面に 関する記述に合致する遺構を求めることで、その信憑性を確認する ことにその主眼を置いてきたといっても過言ではない。すなわち、 基準となる円（ほとんどはオルケストラの円であるが）がスカエナ に接する場合と、その円がスカエナに接し、かつその円に内接する 正方形に一辺にプロスクニオンが一致する場合があり、後者の例は ヘレニズム時代の東方タイプの劇場 (小アジアの劇場)、たとえばプ リエネやエフェソスなどのごく少数の劇場に見られた。そしてウィ トルウィウスの記述の妥当性を証明することを求めてきた研究の結 果として、ウィトルウィウスの記述に合致する場合と一致しない場 合に分けられ、前者はギリシア型劇場平面の代表例のごとく扱われ、 後者はその他多数のものとして放置され、舞台と客席の位置関係の 観点からの研究がなされてこなかったのが現状である。わずかにフ オンゲルカンらがエピダウロスの劇場の分析において基準となる円 に内接する正五角形がプロスケニオンの位置に一致すること明らか
にし、正方形以外にも基準となる円に内接する正多角形が意味をも つことを指摘している。(9)

\section{3. 基淮となる円の設定について}

劇場の客席と舞台建築の位置関係を分析する上で基準となる円 を、既往の研究では実は確たる根拠もなくオルケストラの円に定め ている場合が多く、それ以外の円が設定される場合でも統一された 原則があるわけではない。 ${ }^{(10)}$ 基準となる円の設定方法が確定しない 原因はウィトルウィウスの記述の曖昧さに起因している。彼は第 5 書、第 7 章、第 1 節のギリシア劇場の平面割り付けの手続きの説明 の中で、基準となる円を「底の円」ima circinatione と表現してい る。ローマ劇場の説明でも同じように「底面の周」perimetros imi という表現を用いている。つまりオルケストラとは一言も述べてい ないのである。一方で、同じ書の第 6 章、第 5 節のローマ劇湯の説 明では「オルケストラは一番下の階段席間と同じ直径をもつ」と述 べている。つまりウィトルウィウスはオルケストラの円は客席最下 段の円と同一であることを前提として劇場平面の割り付けを行って いると解釈できる。

しかしながら、実際の遺構は必ずしもそうではなく、両者が異な る直径の円をなすことがしばしば見受けられる。なぜならオルケス トラと客席の間にエウリポス euripos と称される通路兼排水路部分 が挟まれる場合が見受けられたり、あるいはオルケストラ周りに背 もたれと时掛けの付いた貴賓席が設置され、その背後に通路を挟ん で客席が取り囲む場合もある。（図 2）彼が生きていた時代に両者が 一致しない例が実在していたことから、そうした劇場を知らなかっ たとは推測しにくい。あるいはそうした劇場の存在を充分承知した 上で、基本的な理論を述べるために簡略化した平面を想定して述べ たか、あるいは「底の円」というきわめて暧昧な表現を意図的に用 いることで基準となる円がどのようにも設定できることを想定して いたとも考えられる。このことから、本稿では才ルケストラの円と 客席最下段の円が同一でない場合には、その両方が基準の円となる 可能性があると見なし、その円とそれに内接する正多角形の中で現 存遺構に最も一致する幾何学図形を求めた。なお本稿では、2つの 円が一致しない場合、寸なわちオルケストラ周りに貴賓席やエウリ ポスが置かれる場合には、客席両端部の支持壁の内側端部が終わる 地点に繋がる円弧で、かつその貴賓席の内側、あるいはエウリポス の外側の円弧に従う円を客席最下段の円と以下では表記する (図2)。

\section{4. 分析結果}

ヘレニズム時代末までにギリシアで建設された劇場の中で、客席 と舞台建築との位置関係が明瞭な 23 例についての分析結果を表 1 にまとめた。表 1 には、左欄から右に、劇場の位置する都市名、分 析対象の劇場名、最初の建設年代、客席や舞台建築各部の建設年代、 エウリポスの有無、客席と舞台建築を結び付ける幾何学図形の種類、 その幾何学図形の一致する場所、幾何学図形の基準となる円の種類、 基準となる円の半径、基準となる円の中心から幾何学図形が一致す る場所までの実測距離、基準となる円の中心から幾何学図形が一致 する場所までの理論上の距離、前者 $2 つ の$ 誤差（すなわち理論值と 実測距離との差) が記されている。各部の寸法の取り方は図 2 に示 し、各劇場における実測值と図面はそれぞれの発掘報告書より収集 した。(11) 実測寸法が不明であるが、図面が入手できた 5 例（基準と なる円の半径や誤差が末記入の劇場）については図面上のみで適合 
表 1 ギリシアからヘレニズム時代のギリシア劇場における客席と舞台建築との位置関係

\begin{tabular}{|c|c|c|c|c|c|c|c|c|c|c|c|c|c|c|}
\hline & \begin{tabular}{|} 
分析対象の劇場名 \\
称もしくはは区別
\end{tabular} & 最初の建設年代 & 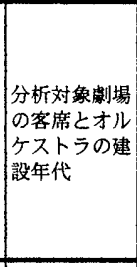 & 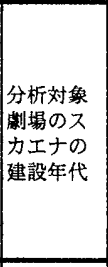 & 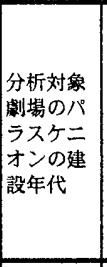 & 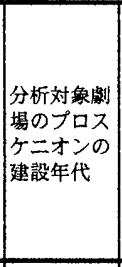 & \begin{tabular}{|l} 
エウ \\
リホポ \\
スの \\
有
\end{tabular} & 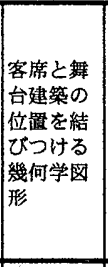 & 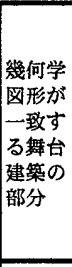 & 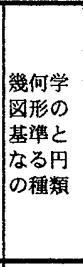 & 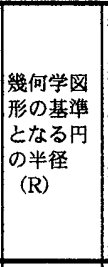 & 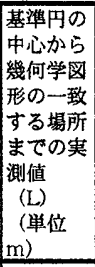 & 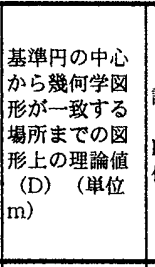 & 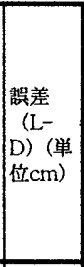 \\
\hline ソリコス & & 前500年頃 & 同左 & - & - & - & 無 & なし & & & & & & \\
\hline メガロポリス & 第1期の劇場 & 前350-前329年 & 同左 & 同左 & E & E & 有 & なし & & & & & & \\
\hline アテネ & $\mid$\begin{tabular}{|c|} 
ティオニソス殿場 \\
(リュクルコス时) \\
(时)
\end{tabular} & 前6世紀 & $\begin{array}{l}\text { 前338年-前 } \\
326 \text { 年 }\end{array}$ & 同左 & 同左 & 同左 & 有 & 内 & パラ & オル & 9.81 & 9.87 & 9.81 & 6 \\
\hline 术セイデイオン & 第2期の麡場 & $\begin{array}{l}\text { 前5世紀末加ら前4 } \\
\text { 世紀初め }\end{array}$ & 前4世紀末 & \begin{tabular}{|l|} 
前3世紀初 \\
\end{tabular} & - & \begin{tabular}{|l} 
前3世紀初 \\
\end{tabular} & 有 & 正六角形 & プロ & オル & 6.9 & 5.96 & $\begin{array}{l}\mathrm{R} \times \cos 30^{\circ} \\
5.975\end{array}$ & -1.5 \\
\hline |エレトリア & $\mid$ 第2期と3期の殿場 $\mid$ & 紀元前4世紀中頃 & \begin{tabular}{|l} 
紀元前3世紀 \\
初め
\end{tabular} & \begin{tabular}{|l|} 
前 4 世紀中 \\
䋶
\end{tabular} & $\begin{array}{l}\text { 第2 } 2 \text { 期は前 } \\
3 \text { 紀初 } \\
\text { 第3期は } \\
\text { 前2仕紀加 } \\
\text { 前198年 } \\
\text { 以降) }\end{array}$ & 同左 & 有 & 正八角形 & プロ & 客 & 11.02 & 10.32 & $\begin{array}{l}\mathrm{R} \times \cos \left(45^{\circ}\right. \\
/ 2)=10.18\end{array}$ & 14 \\
\hline カソッペ & 剧場 & 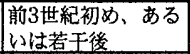 & 同左 & 同左 & 同左 & 同左 & 無 & 正五角形 & プロ & オル & 9 & & & 図上 \\
\hline トドーナ & 第1期の劇場 & 椾297-前272年 & 同左 & 同左 & 同左 & 同左 & 有 & な & & & & & & 図上 \\
\hline エギラ & 第1期の溇埸 & 前 280 年一前 250 年 & 同左 & 同左 & 同左 & 同左 & 有 & 正六角形 & プロ & 客 & 9.95 & 8.58 & $\begin{array}{l}\mathrm{R} \times \cos 30^{\circ}= \\
8.617\end{array}$ & -3.7 \\
\hline コリントス & 第2 2 期の湟場 & 前 415 年 & \begin{tabular}{|l} 
前338年から \\
前250年
\end{tabular} & 同左 & - & 同左 & 有 & 正六角形 & スカ & 客 & 11.7 & 10.05 & $\begin{array}{l}R \times \cos 30^{\circ}= \\
10.032\end{array}$ & 1.8 \\
\hline マンティネア & & 前4世紀 & $\begin{array}{l}\text { 前2222年以降 } \\
\text { のへレ二ズム } \\
\text { 時代 }\end{array}$ & 同左 & 同左 & 同左 & 有 & 正五角形 & プロ & オル & 10.04 & 8.16 & $\begin{array}{l}\mathrm{R} \times \cos 36^{\circ}= \\
8.12\end{array}$ & 4 \\
\hline ドドーナ & 第2期の劇場 & 不明 & $\begin{array}{l}\text { 前297-前272 } \\
\text { 年 } \\
\end{array}$ & \begin{tabular}{|l} 
前3世世紀末 \\
(前219年 \\
以降) \\
\end{tabular} & 同左 & 同左 & 有 & 正六解形 & プロ & 客 & \begin{tabular}{|l|} 
報告書記 \\
誐なし \\
\end{tabular} & & & 因上 \\
\hline カソッペ & 小劇場（第2期） & 前3世紀 & 前3世紀末 & 同左 & 同左 & 同左 & $\begin{array}{ll}\text { 無 } \\
\end{array}$ & 田 & 2⿰力口 & オル & 8.15 & & & 図上 \\
\hline ネア・ブレウロン & & 前3世紀 & 同左 & 同左 & 同左 & 同左 & 無 & 正三角形 & プロ & オル & 5.8 & 2.99 & $\begin{array}{l}\mathrm{R} \times \cos 60^{\circ} \\
=2.9\end{array}$ & 9 \\
\hline テロス & & \begin{tabular}{|l} 
前4世紀末加ら紀元 \\
前246年
\end{tabular} & 前246年 & 同左 & - & 前180年 & 無 & 円 & スカ & オル & 10.5 & 10.6 & 10.5 & 10 \\
\hline デルフィ & & $\begin{array}{l}\text { 前3世紀末から前 } \\
160 \text { 年頃 }\end{array}$ & 同左 & 同左 & 同左 & 同左 & 有 & 正五角形 & プロ & オル & 9.25 & & & 図上 \\
\hline アテネ & 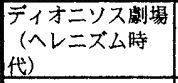 & 前6世紀 & \begin{tabular}{|l} 
前338年-前 \\
326年
\end{tabular} & \begin{tabular}{|l} 
紀完前2世 \\
紀中项よ \\
若而前 \\
\end{tabular} & 同左 & 同左 & 有 & 正六角形 & プロ & 客 & 13.55 & 11.71 & $\left|\begin{array}{l}\mathrm{R} \times \cos 30^{\circ} \\
11.734\end{array}\right|$ & -2.4 \\
\hline エピダウロス & & 前300年頃 & 前300年頃 & $\begin{array}{l}\text { 前2世世紀中 } \\
\text { 䋶 }\end{array}$ & 同左 & 同左 & 有 & 正六角形 & プロ & 客 & 12.39 & 10.81 & $\begin{array}{l}\mathrm{R} \times \cos 30^{\circ}= \\
10.73\end{array}$ & 8 \\
\hline シキオン & & 紀元前3世紀前半 & 同左 & $\begin{array}{l}\text { 紀元前2世 } \\
\text { 紀中比 }\end{array}$ & 同左 & 同左 & 有 & 正五角形 & プ & 客 & 11.62 & 9.4 & \begin{tabular}{l|}
$\mathrm{R} \times \cos 36^{\circ}$ \\
9.40
\end{tabular} & 0 \\
\hline メガロポリス & 第2期の剧場 & 前350-前330年 & 同左 & \begin{tabular}{|l} 
前3世紀前 \\
半 \\
\end{tabular} & - & \begin{tabular}{|l} 
前2世紀中 \\
䫓 \\
\end{tabular} & 有 & 正五角形 & プ & 客 & 17.28 & 13.97 & $\begin{array}{l}\mathrm{R} \times \cos 36^{\circ}= \\
13.980\end{array}$ & -1 \\
\hline オロポス & 第2期の劇場 & 前4世紀 & 前3世紀 & 前 3 世紀 & - & 前150年頃 & 無 & 正六角形 & プロ & オル & 6.18 & 5.55 & $\begin{array}{l}\mathrm{R} \times \cos 30^{\circ}= \\
5.352\end{array}$ & 19.8 \\
\hline ペイライエウス & & 前150年頃 & 同左 & 同左 & 京左 & 同左 & 有 & 正八解 & プ & 客 & 11.7 & $\begin{array}{l}10.83 \\
(8.2) \\
\end{array}$ & $\begin{array}{l}\mathrm{R} \times \cos \left(45^{\circ}\right. \\
/ 2)=10.783 \\
\end{array}$ & 4.7 \\
\hline オエニアダエ & & 前3些紀 & 同左 & 同左 & 同左 & 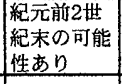 & 無 & 正方形 & プ & 客 & 11.25 & 7.84 & $\begin{array}{l}\mathrm{R} \times \cos 45^{\circ}= \\
7.955\end{array}$ & $\mid-11.5$ \\
\hline メッセネ & オデイオン & $\begin{array}{l}\text { レニニズム時代 } \\
\text { (帝政初期の可能 } \\
\text { 性あり) }\end{array}$ & 同左 & 同左 & $?$ & 同左 & 無 & 円 & スカ & オル & 9.7 & & & 因上 \\
\hline
\end{tabular}

前沈紀元前を意味する。

図上は図面上のみで客席と舞台建築との関係を分析したことを意味する。

オルケストラの円の部分の存在 : ○はオルケストラの円の部分が磪保されている、×はオルケストラの円が舞台建築で遮られていることを意味する。

プロ: プロスケニオン、パラ:パラスケニオン、スカ:スカエナ、オル : オルケストラの円、客 : 客席最下段間の距離を直径とする円、一: 該当する建物なし。

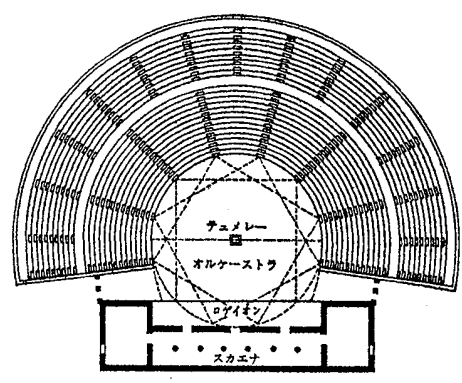

図 1 ウィトルウィウスによる ギリシア劇場の割り付け方法

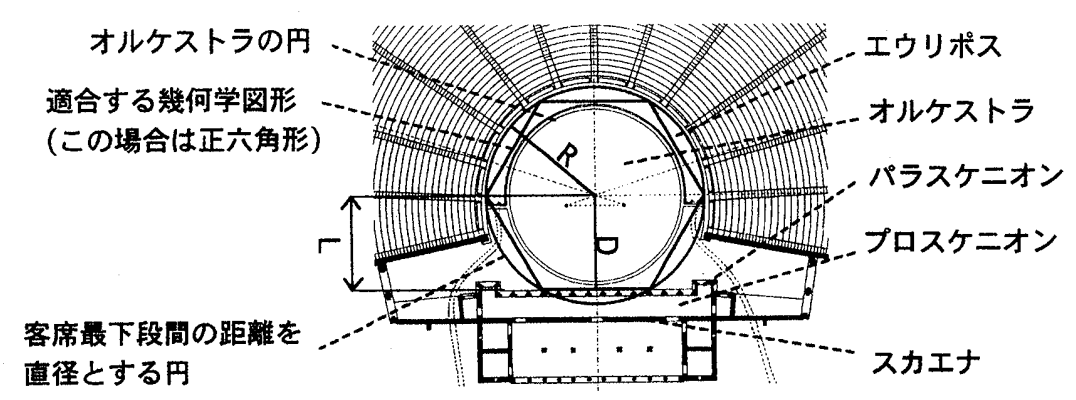

図 2 エピダウロスの劇場の中央部平面図と

表 1 のための劇場各部の寸法の取り方を示寸図 
する幾何学図形を求めた。その際の図面縮尺は $1 / 200$ から 1/400の 間にあり、本稿の場合その誤差は最大 $50 \mathrm{~cm}$ ほどになる可能性もある。 (12) したがって、この5つの劇場(図 3)の客席と舞台建築の位置の間 には表 1 に見られるような関係が存在する可能性が高いと解釈すべ きであろう。

\section{4-1. 基淮となる円の種類}

ギリシアにおける演劇はアルカイック期にまで遡るが、遺構が確 認できる最初期の劇場は紀元前6世紀のソリコスThoricusにおいて である。紀元前 6-5 世紀頃の劇場のオルケストラ平面の形は確定し ておらず、円形、四角形状あるいは台形状が提案され、傾斜地の一 方か、しくはオルケストラを取り囲むように客席が造られていた。 この頃の劇場では、舞台建築が確実に造られていたと確定できるも のはなく、まったく造られていなかったか、あるいは木造の仮設の ものが建てられていた可能性が指摘できるのみである。したがって、 円形のオルケストラを囲むように扇形あるいは馬蹄形平面の客席が 巡り、反対側に舞台が建てられた形式を遺構として最初に確認でき るのはリュクルゴス時代（紀元前 338 年から紀元前 326 年）のアテ ネのディオニソス劇場まで待たなければならない。(図 4)この劇場 において初めて円形平面のオルケストラ、舞台建築、客席の三つが 揃った劇場が確認できるのである。(13)

上記の三つが揃った劇場において、オルケストラの必ずしもすぐ 外側に客席が円弧状に並んでいるわけではなかった。表1にみられ るように、ヘレニズム時代までにギリシアで建設された劇場でオル ケストラと客席最下段の円が一致する場合が 7 例、両者の円の大き さが異なる場合が 15 例、オルケストラの平面が確定できないものが 1 例であった。また、前述したように、ウィトルウィウスは基準と なる円の記述においてきわめて曖昧な表現をしている。以上の 2 点 から本稿では基淮となる円をオルケストラの円と客席最下段の円弧 に沿う円の 2 通りが可能であり、その 2 つ場合で客席と舞台建築 の位置関係の分析を行った。

まず基準となる円について見ると（表 1)、オルケストラの平面 が不明であったり、あるいはオルケストラもしくは客席最下段間の 距離を直径とした円よりも外側に舞台建築が配置されている場合の 3 例（ソリコス、メガロポリス Megalopolis とドドーナDodona の第 1 期の劇場）を除く 20 劇場の中で、ネア・プレウロンNea Pleuron の劇場など9例はオルケストラの円を基準とし、エレトリアEretria の劇場など 11 例は客席最下段の円を基準としていることが明らか となった。また、オルケストラと客席最下段の円弧がなす円の直径 が一致しない劇場 15 例では、どちらの円も客席と舞台建築との位置 関係を定める幾何学図形の基準の円になりうる可能性を持っている。 なぜなら 15 例の中で 10 例は客席最下段間の距離を直径とする円が 基準となっているのに対し、3 例はオルケストラの円が基準となっ ているからである。しかも、全体の事例数はそれほど多くないもの の、表 1 に見られるように紀元前 3 世紀以降の直径の異なる $2 つ の$ 円が存在する劇場では客席最下段間の円弧に従う円が基準になる場 合に限定されている。

これらのことから以下の 3 点が指摘できる。まず、分析したほと んどの劇場がオルケストラもしくは客席最下段の円を基隻とし、そ の円あるいはその円に内接する正多角形の一辺が舞台建築の一部に 一致している。つまり、舞台建築と客席部分相互の位置関係を幾何
学図形で結び付ける場合に、基準となる円がオルケストラの円とな る場合と客席最下段の円となる場合の 2 通りあり得ることが実証さ れ、それは紀元前 4 世紀末あるいは紀元前 3 世紀初めからギリシア の地に併存していた。次ぎに、オルケストラの円と客席最下段の円 弧に従う円の直径が異なる場合には、紀元前 3 世紀以降の劇場のほ ぼすべてが後者の円が基準となってその円に内接する正多角形によ って客席と舞台建築の位置が関係づけられている。

\section{4-2.プロスケニオンの位置のもつ意味}

オルケストラ、舞台建築、客席の3つを備えた劇場建築で次に起 こった大きな変化は舞台建築における変化で、とりわけパラスケニ オンとプロスケニオンの出現である。パラスケニオンは本来スカエ ナの側面の建物を意味する言葉で、演劇においてより多くの出入り 口を必要としたことから舞台に付け加えられるようになったと解釈 される。そのパラスケニオンの最古の遺構はリュクルゴス時代再建 のディオニソス劇場であり、その後エレトリアやエピダウロス、お よびティンダリスやセジェスタなどギリシアや南イタリアおよびシ チリアのギリシア植民都市の紀元前 3 世紀以降の劇場で造られてい った。しかしながら、一般的傾向としてヘレニズム時代以降の劇場 では建設されることは次第に少なくなっていった。(14)

一方、プロスケニオンはその定義の曖昧さも手伝って、その出現 の時期があまり明確ではない。プロスケニオンは言葉の意味として はスカエナの前に造られた部分を指すのであるが、その部分全体を

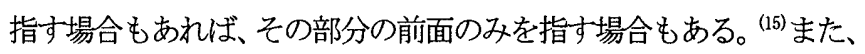
プロスケニオンを造ることで生まれた屋根面が屋根ではなく、上演 者が演じる高い台となった時にはその台の上面部分をロゲイオンと 称している。しかしながら、プロスケニオンが造られた場合に常に ログイオンが存在していたと確定できる、すなわち、高くなった部 分に上演のための舞台が設置されていたと断言できるわけではない。 さらにプロスケニオンの高さの程度によってロゲイオンの存在を決 定できるわけでもない。(16)

現存する遺構からみると、紀元前 3 世紀初めにエレトリアで、紀 元前280-250年にエギラ Aegiraで石造のプロスケニオンが造られて いる。また、タソス Thasos の大理石製プロスケニオンの建設時期は 紀元前 3 世紀初めと見なされている。ポセイデイオン Poseideion ( 現代名 Isthmia) の劇場が紀元前 4 世紀末から紀元前 3 世紀初めに 再建された際に、舞台両側に造られた斜路が確認されており、その 斜路はプロスケニオンに上るためのものであると指摘されている。 これに対して、南イタリアやシチリアのギリシア植民都市に残る劇 場は、紀元前 4 世紀末から紀元前 3 世紀初めの時期にプロスケニオ ンを備えていたのではないかと指摘されている。たとえばロークリ では木製の柱用の柱穴を備えた石材が並び、これらが舞台を支持し ていたのではないかと見られており、その建設年代が紀元前 4 世紀 中頃と想定されている。またモルガンティーナの劇場ではロゲイオ ンを支持していた 4 本の円柱が確認されており、紀元前 4 世紀末か ら紀元前 3 世紀初めに建設されたと見られている。(17)

紀元前 250 年作成と見られるデロス島の劇場建設工事費支払い に関する碑文の中で、紀元前 280 年の支払い部分にプロスケニオン 工事に関する記述が確認されている。また、高くなった舞台、すな わちロゲイオンを舞台建築に必要とした背景に紀元前 4 世紀末から 紀元前 3 世紀初め頃より流行した新喜劇の存在があげられる。演劇 

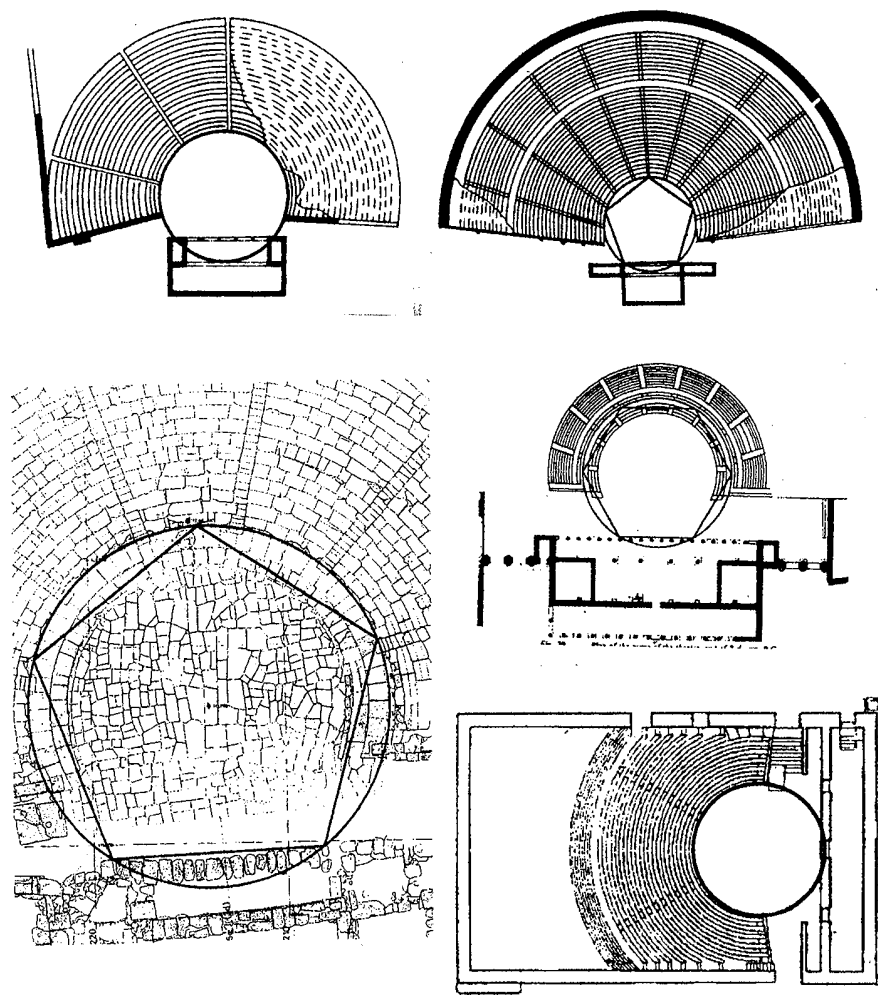

図3図面上で舞台建築と客席の位置関係を分析した事例 (上段左と右 : カソッぺの小劇場と劇場、左下段 : デルフィ、右中段 : ドドーナ(第 2 期)、右下段:メッセネ、)

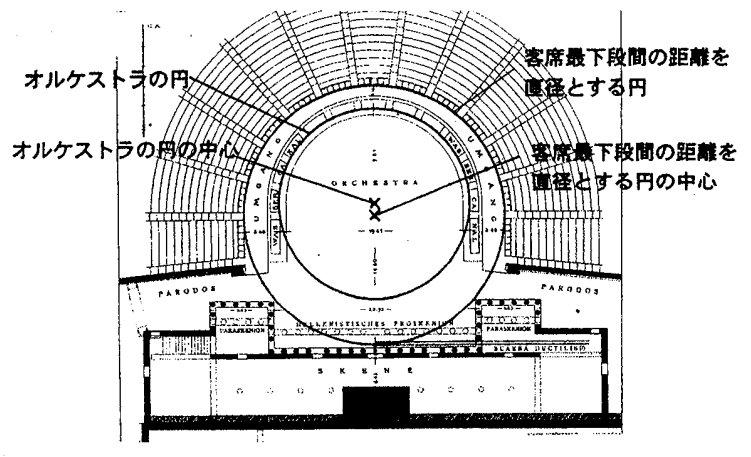

図 4 ディオニソス劇場中央部の平面図

の主流がコーラスや舞踊を中心とした従来の悲劇やサテュロス劇か ら、台詞を主とした役者による演劇人と変化したのである。それは 役者の言葉をより聞き取り易く、かつ役者の所作を見やすくするこ とを必要とし、その結果として役者を高くなった舞台の上に置くこ とを求めることとなった。これらの点から考慮して、ロゲイオンを 伴ったプロスケニオンは遅くとも紀元前 4 世紀末から紀元前 3 世紀 初めには出現していたと見て間違いないであろう。(18)

客席と舞台建築の位置に幾何学図形によるなんらかの関係が見 られる20 例についてみると（表 1)、15 例がプロスケニオンの位置 に、4例がスカエナの位置に、1 例がパラスケニオンの位置にその幾 何学図形が一致している。すなわち、客席と舞台建築の位置関係を 幾何学図形によって結び付ける場合に、そのほとんどの劇場でプロ スケニオンが決定的役割を果たしているのである。

パラスケニオンの位置が幾何学図形で舞台建築と客席の位置関 係を関係づける上で意味を持つのはアテネのリュクルゴス時代のデ
イオニソス劇場である（表 1)。この劇場では、オルケストラの半径 は $9.81 \mathrm{~m}$ で、その中心からパラスケニオンまでの距離は $9.87 \mathrm{~m}$ であ り、ほとんど等しい。つまり、オルケストラの円に接するようにし てパラスケニオンが置かれている。それに対して、ウィトルウィウ スが述べているように、オルケストラの円に接する位置にスカエナ が置かれているのは紀元前 246 年に造られたデロスの劇場と ${ }^{(19)}$ 、カ ソッペCassope に紀元前 3 世紀に建設され、同世紀末に再建された 小劇場、通称ブーレウテリオンのみに確認できる(表 1 と図 3 左上)。

一方、紀元前 4 世紀末に石造で再建されたポセイデイオンの劇場 では、オルケストラの円に内接する正六角形の一辺の位置にプロス ケニオンが一致している(表 1)。また、紀元前 3 世紀初めに客席が 再建され、従来のスカエナにプロスケニオンが新たに付け加えられ たエレトリアの劇場では客席最下段の円に内接する正八角形の一辺 がプロスケニオンに一致している(表 1)。したがって、プロスケニ オンが出現したと考えられている紀元前 4 世紀末もしくは紀元前 3 世紀初めの劇場において、すでにプロスケニオンの位置が客席と舞 台建築の位置関係を定める上で最も重要な役割を果たしていたこと になる。このことは、プロスケニオンが出現したとして現存遺構か ら確認できる最初期の時期、すなわち恒久的なプロスケニオンが劇 場建築に用いられ始めた当初から、プロスケニオンが客席と舞台建 築の位置を幾何学図形で関係づける役割を担っていたことを意味し ている。

\section{4-3. 客席と舞台建築の位置を関俰づける幾何学図形}

客席と舞台建築相互の位置関係を決定づける幾何学図形は種々 雑多というわけではなく、円 (4 例) と正多角形 (16 例) に限定さ れていることが表 1 から読み取れる。つまり、客席と舞台建築の位 置を関係づける幾何学図形としては円よりも、正多角形が圧倒的に 多く一致することが明らかとなった。円が客席と舞台建築の位置を 関係づける場合はすべて、アテネのリュクルゴス時代のディオニソ ス劇場(紀元前 338 年から紀元前 326 年)などオルケストラの円で、 その円はパラスケニオンやスカエナの壁の位置に一致し、紀元前 3 世紀以前に建設されたものである。

次に客席之舞台建築の位固を関係づける幾何学図形が正多角形 をなす場合の 16 例の中で（表 1)、正三角形や正方形が意味を持つ 場合はそれぞれネア・プレウロンの劇場（紀元前 3 世紀）と才エニ アダエ Oeniadae（紀元前 3 世紀あるいは紀元前 2 世紀末) の劇場(20) のみで、正五角形の場合はカソッペ (紀元前 3 世紀初め)、メガロポ リス (第 2 期、紀元前 2 世紀中頃)、マンティネア Mantinea（第 2 期、紀元前 222 年以降のヘレニズム時代)、デルフィ(紀元前 3 世紀 末から紀元前 160 年頃)、シキヨンの劇場 Sikyon（紀元前 2 世紀中 頃）の 5 例であった。正六角形の一辺が舞台建築のスカエナもしく はプロスケニオンの位置に一致する場合はポセイデイオン(第 2 期、 紀元前 3 世紀初め)、エギラ. (紀元前 280-紀元前 250 年)、コリント ス（紀元前 338 年から紀元前 250 年）、ドドナ（第 2 期、紀元前 3 世紀末)、アテネのディオニソス劇場 (ヘレニズム期、紀元前 2 世紀 中頃より若干前)、エピダウロス (紀元前 2 世紀中頃)、オロポス Oropos（紀元前 150 年頃）の7例であり、正八角形が意味を持つ場 合はエレトリア（第 2 期、紀元前 3 世紀初め）とペイラエウス（紀 元前 150 年頃) の 2 例であった。このことからオルケストラあるい は客席最下段の円弧に沿った円に内接する正多角形の中でも、従来 
の研究者が指摘してきたような正方形は少なく、とりわけ正五角形 と正六角形のような正方形以外の正多角形の一辺が舞台建築のスカ エナもしくはプロスケニオンの位置に一致する場合がきわめて多い ことが明らかとなった。

このように正多角形を介して客席と舞台建築の位置を関係づけ る場合、その一辺が一致する場所は 16 例中で 15 例がプロスケニオ ンの場所においてであり、ヘレニズム時代のコリントスの劇場でス カエナの位置に一致する 1 例のみが例外として確認された。さらに、 その正多角形の種類は紀元前 3 世紀の段階では正五角形と正六角形 がほとんどであり、それ以外では正三角形による関係づけがネア・ プレウロンでみられるのみである。紀元前 2 世紀以降になって正方 形や正八角形による関係づけが確認できる。また、これらの正多角 形の種類を地域的にみても、特定の地域に特定の正多角形が集中す る傾向はまったくみられない。

前述したように、客席と舞台建築の位置を関係づける幾何学図形 の基準となる円にはオルケストラの円と客席最下段の円の 2 通りが 併存していた。そこでオルケストラの円と客席最下段の円のどちら の円に内接する正多角形が客席と舞台建築の位置関係に意味を持つ かを見てみると、5例の劇場がオルケストラの円に、11例の劇場が 客席最下段の円に内接する正多角形に意味があった。また、オルケ ストラの円に、あるいは客席最下段の円に内接する正多角形の種類 を概観してみると、オルケストラの円の場合では正三角形が 1 例、 正五角形と正六角形が 2 例ずつであった。一方、客席最下段の内の 場合では正方形が 1 例、正五角形が 3 例、正六角形が 5 例、正八角 形が 2 例であった。したがって、基準となる円がオルケストラであ ろうと、客席最下段の円であろうとその区別に対して客席と舞台建 築の位置を関係づける正多角形の種類が特別の関係持つとはいえな い。

\section{4 オルケストラの円と客席最下段の円の中心がずれる劇場につい}

\section{$\tau$}

アテネのリュクルゴス時代およびへレニズム時代のディオニソ ス劇場（図 4)、コリントスのヘレニズム時代の劇場、オエニアダエ とペイライエウスの劇場の 5 つでは、オルケストラの円の中心は客 席最下段の円の中心よりもそれぞれ $1.21 \mathrm{~m}$ (ディオニソス劇場の二 つの時期で二つの円の中心のずれは同じ）、1.495m、0.60m、0.70m 客席側にずれている。(21)その結果、客席とオルケストラの間の幅は 客席の両端部で最も広く、その中間点で最も狭くなっている。さら にオルケストラの円は舞台建築に遮られることなく確保されている。

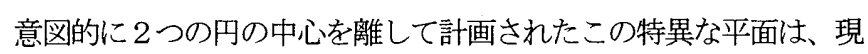
在までに上記の 5 つの劇場のみで確認されている。その平面の出現 の背景として、劇場建築の時代的な変化と上演形式に対する地域的 なこだわりが指摘されてきた。すなわち、舞台と客席を近づけるよ うな劇場の作り方が一般化する一方で（つまりオルケストラの円は 舞台建築で切断される)、アテネ近郊の都市ではオルケストラ全体を 使うコーラスと踊りを主とする古典劇の伝統がきわめて強く保たれ ていた（つまりオルケストラの円部分は残されねばならない)。(22)

オルケストラの円をなす部分を確実に確保し、その内側に舞台建 築を配置しない方法は古い時代の劇場においてより重視されていた と見て間違いない。なぜなら、本稿で分析対象として取り上げた 23 例の中 12 例ではオルケストラの円部分が確保されている。その中で
2 つの円の中心がずれる 5 例を除く 7 例は、エピダウロスの劇場を 除き、すべて紀元前 3 世紀前半までに建設された劇場である。その 典型的な例としてメガロポリス（紀元前 350-330 年）やドドーナの 第 1 期の劇場（紀元前 297-272 年）があげられ、これらの劇場では 客席と舞台建築の位置関係に関して特定の幾何学的な関係はみられ ず、むしろオルケストラの円の外側に舞台建築を配置することのみ が目指されているように見受けられる。

客席最下段とオルケストラの円の中心がずれる特異な平面形式 の最古の例であるアテネのリュクルゴス時代のディオニソス劇場で は、客席最下段の円より若干外側にスカエナの壁が置かれる一方(プ ロスケニオンは持っていない)、オルケストラの円に接する位置にパ ラスケニオン前面が置かれている。ここに、客席最下段の円やオル ケストラの円よりも常に外側に舞台建築を配置しておきたいという 意図が読み取れる。しかし紀元前 3 世紀以降になると、2つの円の 中心がずれる劇場でも客席と舞台建築の配置には幾何学図形を介し た関係をはっきりと見いだせる。まず紀元前 338-250 年の時期に再 建されたコリントスの劇場ではオルケストラの円のわずかに外側に プロスケニオンが置かれている一方で、客席最下段の円に内接する 正六角形の一辺がスカエナの位置に一致することが明らかになった (表 1)。(23)紀元前 3 世紀建設とされるオエニアダエの劇場では客 席最下段の円に内接する正方形の一辺がプロスケニオンの位置に一 致することが今回の分析で明らかになり、それと同時にオルケスト ラの円をなす縁石の外側がパラスケニオンの位置にほぼ一致してい る。(24)

次に、紀元前 2 世紀の中頃に改築されたアテネのディオニソス劇 場の改築されたパラスケニオンは従来のものより後退し、プロスケ ニオンが新たに造られ、客席部分とオルケストラ部分には大きな変 更は受けなかった。その際に、オルケストラの円は舞台建築に遮ら れずに、客席最下段の円に内接する正六角形の一辺にプロスケニオ ンの位置が一致することが新たに判明した（表 1 ）。また、ペラエ ウスの劇場はディオニソス劇場よりも若干遅く建設されたとみられ るが、オルケストラの円の外側に舞台建築そのものが位置しながら、 ここでも客席最下段の円に内接する正八角形の一辺がプロスケニオ ンに一致することが分析より明らかとなった（表 1)。この劇場の特 筆すべき点は、そうした結果を得ながらも、オルケストラの円と客 席最下段の円の中心のずれはきわめて小さくなっていることである。

以上のことから、客席とオルケストラの円の中心がずれる平面は 単にオルケストラの円を確保しつつも、客席と舞台をできるだけ近 づけた結果として生まれたものでないことが明らかである。むしろ 客席と舞台の位置を幾何学図形によって関係づけた上で、オルケス トラの円が確保できるようにその位置を客席側に寄せるという特殊 な手法として生み出されたものとみなすべきである。

前述したように、客席と舞台建築の位置を幾何学図形で関係づけ る手法は紀元前 4 世紀末からの多くの劇場で行われていた。特に、 紀元前 4 世紀末あるいは紀元前 3 世紀初め以降にプロスケニオンが 石造化すると、プロスケニオンの位置に基淮となる円に内接する正 多角形の一辺を一致させる場合がきわめて多くみられるようになっ た。その結果、オルケストラの円はプロスケニオンによって遮られ ることとなり、オルケストラそのものを円形平面として確保するこ とはできなくなっていた。仮に客席最下段の円に内接する正多角形 
の一辺にプロスケニオンの位置が一致し、同心円のオルケストラの 円も確保するならば、オルケストラの円の周りに必要以上の幅の通 路ができ、客席が舞台から遠く離れてしまうか、あるいはオルケス トラの円が小さくなり過ぎてしまう。それを避ける方法は客席最下 段の円の中心からオルケストラの円の中心を客席側に移動させるこ とである。

5.まとめ

ギリシアにヘレニズム時代までに建設された劇場の中でその遺構 の状態が明瞭な 23 例を対象として客席と舞台建築の位置関係につ いての分析を行った結果、以下の諸点が明らかとなった。

- 既往研究では、客席と舞台建築部分相互の位置関係を基準となる 円もしくはその円に内接する正方形によって関係づけてきた。し かし、本研究によって両者を関係づける図形として正三角形、正 五角形、正八角形が考えられることが複数の遺構で確認できた。 ・両者を結び付ける基準となる円はオルケストラの場合と客席最下 段が描く円の場合の 2 通りが併存していた。

・ 現存遺構から見る限り、劇場に恒久的なプロスケニオンが出現し た時期以降（紀元前 4 世紀末から紀元前 3 世紀初めの間）、基準 となる円に内接する正多角形の一辺はプロスケニオンの位置に 一致することがきわめて多くなった。

・アテネ周辺のきわめて限られた地域の少数の劇場において、プロ スケニオンの位置が客席最下段が描く円に内接する正多角形の 一辺に一致しながら、一方ではオルケストラの円も確保する特殊 な位置関係が客席と舞台建築との間に見られる。

\section{注}

注1）拙稿、「ギリシア・ローマ時代の劇場建案について、日本建築学会九州支部 研究報告集、第 39 号、2000 年 3 月、 pp. 529-532。

注2）表 1 に取り上げられた 23 の劇場以外に、ディウムDium（紀元前 200 年頃) とタソス Thasos（紀元前 3 世紀第 1 四半期）の 2 つの劇湯があげられる。た だし、これらの劇場では客席と舞台の配置についての詳細な報告はまだ行わ れておらず、また作製された図面もやや精度の落ちる。

注3) Vitruvius., De architectura, V，6，1-3 (ロ一マ劇揚)、V，7，1 (ギリシ ア劇場)。円とそれに内接する 4 つの正三角形の組み合わせによって客席と舞 台建築各部の位置を関係づけている。理論上はどのような正多角形も可能で あるが、ウィトルウィウスの述べるギリシア劇場とローマ劇揚ではいずれも 正二角形、正方形のみを用い、彼の建築書の中で正十二角形の以上正多角形 で円を細かく分割する事例は見られないことも考慮した。

注4) Vitruvius, op.cit., V, 6, 1, V, 7, 1。

注5) Dörpfelds, W., Das griechische Theater Vitruvs, in A.M., vol. 22, pp. 439 1897, vol. 23, pp. 326, 1898.

注6) プフシュタインはPriene、Termssos、Delos、Assos、Magnesia am Maeander、 Ephessos、Pergamon の劇場を対象に分析を行っている (Puchstein, 0. Die griechische Buhne, Berlin, pp. 46-70, 1901. )。フィーヒターはドゥルプフ エルドの分析結果および自身の分析結果を資料としPriene、Ephesos、Delos、 Magnesia、Termessos、Sagalassos、Patara、Tralles、Magnesia am Maeander のヘレニズム期の劇場を分析対象としている。Priene、Ephesos、Delos は オルケストラの円がスカエナに接し、Magnesia an Maeander、Termessos、 Patara の劇場で炈ルケストラの円に内接する正方形の一辺がヘレニズム 時代のプロスケニオンに一致し、Tralles の劇場ではオルケストラの円もし くはその円に内接する正方形の一辺は舞台の位置に一致していない (Fiechter, E. R., Die Baugeschichtliche Entwicklung des antiken Theaters, München, pp59-66，1914.)。またオロポス、オエニアダエ、ネア・プレウロ ン、シキヨン、メガロポリス、エレトリア、ペイラエウスの各劇場、アテネ
のディオニソス劇場を対象に、客席と舞台建築の位置関倸を結びつける幾何 学図形として円、その円に内接する正方形もしくは紂横比 $1: 2$ の長方形を取 り上げている。しかし、基淮となる円の設定の仕方は事例ごとに異なり、さ らに前述の檤横比 $1: 2$ の長方形にどのような意味があるのか不明である。 (idem, Antiken griechische Theater- bauten, Heft.1-9, Stuttgart, 1930-1950.)

注7）ビーバーはフィーヒターの説をそのまま受け継ぎ、Priene やDelos の劇湯を 例として、ローマ支配下に入った後期へレニズム時代の劇場がウィトルウィ ウスの記述するギリシア型劇揚の割り付け方に充分一致すると考え、S シア もその説を支持した(Bieber, M. The History of the Greek and Roman Theater, Princeton and New Jersey, Princeton Univ. Press, pp. 126-128, 1961, Sear, F. B., Vitruvius and Roman Theater Design, in A. J.A., vol. 94, pp. 249-258, 1980.)。ローマ型劇場における舞台と客席の関係に関する既往研 究およひ新たな知見については别稿で取り扱う予定である。

注8) Dinsmoor, W.B., The Architecture of Ancient Greece, New York, pp. 297-319, 1973.

注9）ただし、正五角形が外接する円はエウリポス周囲の貴賓席の外側か渵く円弧 に沿ったもので、その円が基準として選ばれた理由がはっきりしない (von Gerkan, A. and Müller-Wiener, W., Das Theater von Ephesos, Stuttgart, pp. 76-83, taf. 3, 1961.)。

注10) 例外的にオルケストラの円以外を基準の円と見な寸場合が見られる。たとえ ばフィーヒターはエフェソスやメガロポリスの劇揚ではオルケストラ周りの 水路の縁の円弧、シキヨンでは背もたれ付き客席の後端部が描く円弧に従う 円を基準としているが、そこに統一された基淮があるわけではない(Fiechter， E.R., op.cit., p.60, abb.27, idem, Das Dionysos-Theater in Athens, Stuttgart, pp. 32-33, 1950, idem, Das Theater in Megalopolis, Stuttgart, pp. 27-28, taf. 5, 1931,.)。

注11) 表 1 の資料の出典を本稿ではスペースの関係から以下のような列举形式とす る。 Anti, C., Teatri greci arcaici, Padova, 1947, Arias, P.E., Il teatro greco fuori di Atene, Firenze, 1934, Bulle, H., Untersuchungen an griechischen Theatern, in Abh. Minchen, vol.33, pp. 9-15, tav. 1, 1928, Dakaris, S., Dodona; Archaeological Guide to Dodona, 出版場所不样、 pp. 65-56, 1971, Dörpfeld, W. and Reisch, E., Das griechische Theater, Darmstadt, 1896 (reprinted in 1966), Fiechter, E.R. Die Baugeschichtliche Entwicklung des antiken Theaters, München, 1914, idem, Das Theater in Oropos, Stuttgart, 1930, idem, Das Dionysos-Theater in Athen, IV. Nachträge, Das Theater im Piraieus, Stuttgart, 1950, idem, Das Theater von Sikyon, Stuttgart, 1931, idem, Das Theater in Megalopolis, Stuttgart, 1931, idem, Die Theater von Oiniadai undNea-Pleuron, Stuttgart, 1931, idem, Das Theater in Eretria, Stuttgart, 1937, Fougeres, G., Fouilles de Mantinée, in B.C.H., vol. 14, pp. 248-256, pl, 17, 1890, Gebhard, E. R., The Theater at Isthmia, The Univ. of Chicago Press, Chicago and London, 1973, von Gerkan, A. and Muller-Wiener, W., op. cit., pp. 77-83, taf. 2-4, Gogos, S., Theater und Umgebung, in Klio, vol.68, pp. 6-31, abb. 45, 1986, Hansen, E. and Algreen-Ussing, G. , Fouilles de Delphes, vol. 2, Atlas, Paris, tavv. $5 \mathrm{c}$, 16, 19, 1975, Hoepfner, W. and Schwandner, E. L., Haus und Stadt im klassischen Griechenland, Munchen, pp. 102-103, fig. 64, 68, 1986, McDonald, W. A., The Political Meeting Places of the Greeks, Baltimmore, pp. 204-211, tav. 19, 1943, Pickard-Cambridge, A. W., The Theater of Dionysus in Athens, Oxford, 1946, Polacco, L., II teatro di Dioniso Eleutereo ad Atene, Roma, 1990, Stillwell, R., Corinth, vol.2, The Theater, Princeton, 1952, Requignon, Y. et Replat, J., Le trace du thêâtre de Dèlos, in B.C.H. vol.51, pp.401-422, tav. 16-20, 1927, Rossetto, P.C. and Sartorio, G.P. ed., Teatri greci e romani, Padova, Roma, vol. 2, 1994。 エギラとコリントスの劇場の表 1 中の (L) の值は $1 / 200$ の図面より算出し、マンティネアの劇場の表 1 中の (R) と (L) の值は $1 / 400$ の図面より、デルフィの劇揚では $1 / 100$ の図面より算出した。 
注12）図面が作成された時期の測量技術から、測量時の誤差は $1 / 200$ の縮尺で $5 \%$ ほどが最大で想定される。同じ縮尺の図面をパソコン上で読み込んでもさら に誤差がでるが、測量時の誤差ほど大きくはないであろう。したがって、本

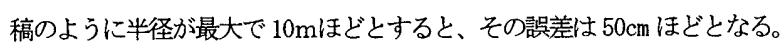
ただし、デルフィの劇場の調査はそれほど古くなく、その実測図面は $1 / 100$ で作成されているので(Hansen, E. and Algreen- Ussing, G., op. cit., tavv. 5c, 1975)、他の 4 つの劇場よりも分析の精度は高く、結果の信頼性も 高い。

注13) 既往の研究に执て、円形平面のオルケストラ、客席、舞台の3つが揃った 劇揚がい頃確立されたがは明らかれされていない。たとえばビーバーは劇 場の明確な建築としての形態は紀元前5 世紀末そして紀元前 4 世紀において 次第に形成されたと見ている (Bieber, M，op.cit., p. 59.)。またローレ ンスやディンズムアは上記3つの揃った劇湯の出現時期について明確に指摘 していない (Lawrence, A. W. Greek Architecture, Yale Univ. Press, New Heaven and London, pp. 205-206, 1996 ( $5^{\text {th }}$ ed. ) , Dinsmoor, W. B., op. cit., pp. 119-120，207-210，246-249.)。また、イズラーは紀元前4 世紀の第 4 四 半期頃をその確立時期とみており、確立の契機となったのがリュクルゴス時 代再建のアテネのディオニソス劇場であると見ている（Isler, H.P., L' architettura teatrale antica, in Rossetto P.C. and Sartorio, G.P. ed, op. cit., vol.1, pp96-98.)。

注14) Bieber, M, op.cit., pp.67-69, Isler, H. P., op.cit., pp. 98-100.

注15) ギリシア語でプロスケニオン proskenion、ラテン語でプロスカエニウム proscaenium と称するが、その意味は研究者によって異なる。例えばディン ズモアはオルケストラとスカエナの間にある列柱であるとし (Dinsmoor, W. B., op.cit., p. 394)、口ゼットはスカエナの前にある舞台であるとする (Rossetto, P.C. and Sartorio, G.P. ed. op.cit,. p. 568)。これに対し て、ビーバーは両者を分けて定義し、プロスケニオンとはスカエナの前にあ る建物で、最古の事例はへレニズム時代造の高、舞台をなすものを、後には 舞台の前面を意味すると定める。一方、プロスカエニウムとは、ローマ人が 用いた言葉て舞台全体を意味し、舞台の前面だけでなく舞台を形成する建筑 も含まれるとする (Bieber, M. op.cit., p.xiii)。

注16)たとえばドウルプフェルドやフォン・ゲルカンは当初プロスケニオンはスカ エナとともに舞台背景をなしていたが、後にその上面部分が舞台として使わ れるようになったと見なす (Dörpfeld, W. and Reisch, E., op.cit., pp. 379ff, von Gerkan, A., Theater von Priene, Munchen, Berlin-Leipzig, pp.73ff，1921.)。それに対しブーレやビーバーなどは当初からプロスケニ オンの上面は舞台として使用されていたと考えている(Bulle, H., op.cit., pp. 234ff, Bieber, M, op.cit., p. 114)。

注17) ポセイデイオンの劇場については Gebhard, E.R., op.cit., pp.51-60.を、 タソスの劇場についてはSalviat, F., Le bâtiment de scène du thèâtre de Thasos, in B.C.H., vol.84, pp. 300-316, 1960 を、ロークリの劇場につい てはArias, P.E., Il teatro greco-romano di Locri Epizefiri, in Dioniso, vol. 5, pp. 188-199, 1941, Mitens, K., Teatri geci e teatri ispirati all' architettura greca in sicilia e nell' Italia meridionale c. 350-50 a,C. Roma, pp.136-139, 1988 を、モルガンティーナの劇場については Stillwell, R. The Theater of Morgantina, in Kokalos, vol.10-11, p. 579ff, 1964-65, ibid, Excavation at Morgantina 1966, in A.J.A., vol. 71, p. 245ff, 1967, Allen, H., Excavation at Morgantina 1967-1969, in A. J.A., vol. 74, pp. 363ff， 1970 を参照

注18) デロス島の劇湯の碑文に関してはDinsmoor, W. B., op. cit, , p. 299, Bieber, M, op. cit., pp. 110-111に詳しい。新喜劇が紀元前 4 世紀末㘦流行する ことについてはビーバーによって概説されており、とりわけその代表者であ るメナンドロスの活躍期がこの時期に相当することがきわめて重要な意味 を持つと見なされている（ibid，pp. 87-107.）。プロスケニオンの出現時期 に関して、既往の研究から見ると、ディンズモアがブーレとともに、紀元前 4 世紀最後の時代に、特に紀元前 315 年から紀元前 292 年の間には仮設の木 造建筑として存在していたのではないかと見ている (Dinsmoor, W. B. , op. cit. pp. 298-299)。これに対して、紀元前 300 年頃にプロスケニオンの
出現年代を設定しているのがビーバーである。ビーバーの考えでは、プロス ケニオンは東方の宮殿建築に起源を持ち、紀元前 300 年頃小アジアの劇場に もたらされ、さらに紀元前 3-2 世紀にか㚈てギリシアの劇場へもたらされた (Bieber, M, op.cit., pp.112-118.)。イスラーも、パラスケニオンが紀 元前 4 世紀に遡る事例は見られないこと、プロスケニオンはパラスケニオン より少し後に出現したと捉え、プロスケニオンの出現時期として紀元前 3 世 紀初め頃を想定している (Isler, H.P., op. cit., p. 100.)。しかしながら、 プロスケニオンの出現時期に関して既往研究はひとつのジレンマに陥って いる。すなわち、現存遺構を客観的に見ても南イタリアやシチリアのギリシ ア植民都市の劇愓のプロスケニオンは紀元前 4 世紀中頃まで遡る可能性があ り、ギリシアでも、たとえばポセイデイオンの劇場のプロスケニオンのよう に紀元前 4 世紀末の可能性もある。しかし劇場建築のモデルとして長く見な されてきたアテネのディオニソス劇場は紀元前 4 世紀後期のリュクルゴス時 代の再建時でもプロスケニオンの存在を確認できていない。モデルとしての ディオニソス劇場よりも古い時代にアテネ以外の地でプロスケニオンが生 み出され、用いられるようになったという理由が見いだせないし、それを客 観的事実として認めがたい雾囲気というものが研究者の間に垣間見える。例 えばポセイデイオンの第2期の劇場のプロスケニオンの建設年代が考古学的 資料から紀元前 4 世紀末も充分にありえるが、著者は紀元前 4 世紀まで遡る ことを躊著し、従来の説とぶつからないように紀元前 3 世紀より古くはない と定めている。(Gebhard, E.R., op.cit., pp.139-141.)。

注19)この点はフィーヒターによってすでに指摘されている(Fiechter, E. R., Die Baugeschichtliche Entwicklung des antiken Theaters, Munchen, p.60, 1914.)

注20)フィーヒターはオルケストラ周りの水路外側の円弧に従った円を基淮とし、 その円に内接する正方形の一辺がパラスケニオンに一致する (Fiechter,

E. R., Das Theater von Oiniadai und Nea-Pleuron, Stiuttgart, pp. 7-18, 1931, idem, Das, Dionysos-Theater in Athens, Stuttgart, pp. 31-32, abb. 13，1950)。しかし筆者はその円の設定の仕方に一貫性がなく筆者の客 席最下段の円の設定基淮に合致しないこと、また正方形の一致する場所がプ ロスケニオンではなく類似例のきわめて少ないパラスケニオンであること から彼の説には大きな疑問が生じる。

注21) Dörpfeld, W. and Reisch, E., op.cit., pp. 50-52（アテネのディオニソス 劇場)、Stillwell，R. op.cit., pp.16-21，pl.III（コリントスの劇場）、 Fiechter, E. R., Das Theater im Piraieus, Stuttgart, taf.6, 1950(ヘำ ライエウスの劇場)、idem, Das Theater von Oiniadae, Stuttgart, p1.1, 1931 (オエニアダエの劇愓)。

注22) Dinsmoor, W. B., op.cit., pp. 312-313.

注23）紀元前 4 世紀に遡るコリントスの第 1 期の劇揚においてスティルウェルは客 席最下段の円に内接する正方形の一辺がプロスケニオンの位置に一致する としているが、この時期のプロスケニオンの位置に確証はなく、また客席最 下段の位置も推定復原にすぎない。客席やプロスケニオンの位置が確定でき るのはへレニズム時代になってからである。（Stillwell， R，op.cit.， pp. 16-27.)

注24) 注(19)参照。Fiechter, E. R., Das Theater von Oiniadai und Nea-Pleuron, Stiuttgart, pp.7-18, 1931, idem, Das, Dionysos-Theater in Athens, Stuttgart, pp. 31-32, abb. 13, 1950.

\section{図版出典}

図 1 : 森田慶一訳注、ウィトルーウィウス建築書(普及版)、p. 321、第18図より、 東海大学出版会、1979 年、図 2 : vonGerkan, A., and Muller-Wiener, op. cit., taf. 12 に筆者が加筆、図 3 : Dakaris, S., Dodona，出版場所不祥、1971，fig. 29 (ドドーナ)、McDonald, W.A., op.cit., tav. 19 (メッセネ)、Hansen, E. et Algreen-Ussing, G., op. cit., tav. 16 (デルフィ)、Dakaris, S., Cassopaia and the Elean Colonies, Athens, 1971, fig. 52,53（カソッペ）のそれぞれに筆者が 加筆、図 4：Dörpfeld, W. and Reisch, E., op. cit., taf.4に筆者が加筆。

（2006年 8 月 14 日原稿受理，2007年 3 月 20 日採用決定） 